\title{
Could Preventing Thromboembolism be a New Hope for COVID-19 Patients?
}

\author{
Marcos Roberto Tovani-Palone ${ }^{1,2 \star}$, Lorenzo Storari ${ }^{3}$, Valerio Barbari ${ }^{3}$
}

\author{
${ }^{1}$ Ribeirão Preto Medical School, University of São Paulo, Ribeirão Preto, BRAZIL \\ ${ }^{2}$ Modestum Ltd, UK \\ ${ }^{3}$ Department of Neuroscience, Rehabilitation, Ophthalmology, Genetics, Maternal and Child Health, University of Genova - Campus of Savona, Savona, ITALY \\ *Corresponding Author: marcos_palone@hotmail.com
}

Citation: Tovani-Palone MR, Storari L, Barbari V. Could Preventing Thromboembolism be a New Hope for COVID-19 Patients?. Electron J Gen Med. 2020;17(6):em250. https://doi.org/10.29333/ejgm/8244

\begin{tabular}{ll}
\hline ARTICLE INFO & ABSTRACT \\
\cline { 1 - 1 } $\begin{array}{l}\text { Received: 28 Apr. 2020 } \\
\text { Accepted: 1 May 2020 }\end{array}$ & $\begin{array}{l}\text { Seval researches have been conducted in order to study treatment effects for COVID-19. Nevertheless, some of } \\
\text { the current treatments have not been effective or recommended for severe cases. In this perspective article, we } \\
\text { briefly discuss the latest developments in the COVID-19 management. }\end{array}$
\end{tabular}

Keywords: COVID-19, SARS-CoV-2, severe acute respiratory syndrome coronavirus 2, pandemics, anticoagulants

\section{INTRODUCTION}

In December 2019, an outbreak of pneumonia due to a novel coronavirus, namely severe acute respiratory syndrome coronavirus 2 (SARS-CoV-2), the virus causing coronavirus disease 2019 (COVID-19); occurred in Wuhan, Hubei province, China. This virus has since spread to many other countries resulting in a pandemic (1-3).

The main symptoms of COVID-19 are similar to other viral upper respiratory illnesses, and include fever, cough, myalgia or fatigue, expectoration, and dyspnea. In addition, a small number of patients can have headache or dizziness, diarrhea, nausea, and vomiting (4), while older patients with comorbidities are more likely to have respiratory failure due to severe alveolar damage. The disease can also show in severe cases a rapid progression to organ dysfunction, with complications, such as shock, acute respiratory distress syndrome, acute cardiac injury, acute kidney injury, disseminated intravascular coagulation, and even death (5).

At present, there are almost 3 million confirmed cases of the disease and about 200,000 deaths worldwide (Figure 1) (6), which has been a major problem for health institutions and authorities (7), as well as to educational, economic and political sectors (8). Although several researches have been conducted in order to study treatment effects for COVID-19 and consequently reduce the mortality rate of the patients, some of the current treatments have not been effective (9) or recommended for severe cases (10). Here, we briefly discuss the latest developments in the COVID-19 management.

\section{COVID-19 AND THROMBOEMBOLISM}

A few days ago, surprisingly, a study demonstrated that SARS-CoV-2 may predispose patients to thrombotic disease, both in the venous and arterial circulations (11). More specifically, this would be due to excessive inflammation, platelet activation, endothelial dysfunction, and stasis related to the infection (12), which can result in severe hypercoagulability and predispose to thrombosis (11). In the current scenario, concomitant venous thromboembolism has been found in many of these patients, especially in severe and critical ill COVID-19 cases. This complication, moreover, has been related to deaths (13).

With that in mind, it is hoped that the use of anticoagulants should be useful in the treatment of severe COVID-19 cases $(14,15)$. However, it should be taken into account that many patients receiving antithrombotic therapy for thrombotic disease can have COVID-19; thus, some aspects, such as choice, dosing, and laboratory monitoring of this therapy may be important in this context (12).

Despite this, the management of COVID-19 patients with use of anticoagulants will not be an easy task due to the complexity between antithrombotic therapy and coagulation disorders (13). Furthermore, this should be even more difficult in countries with a dengue endemic, such as Brazil, where people infected by dengue virus may have contraindication to this therapy or predisposition to serious complications resulting from self-medication with anticoagulants (16). 


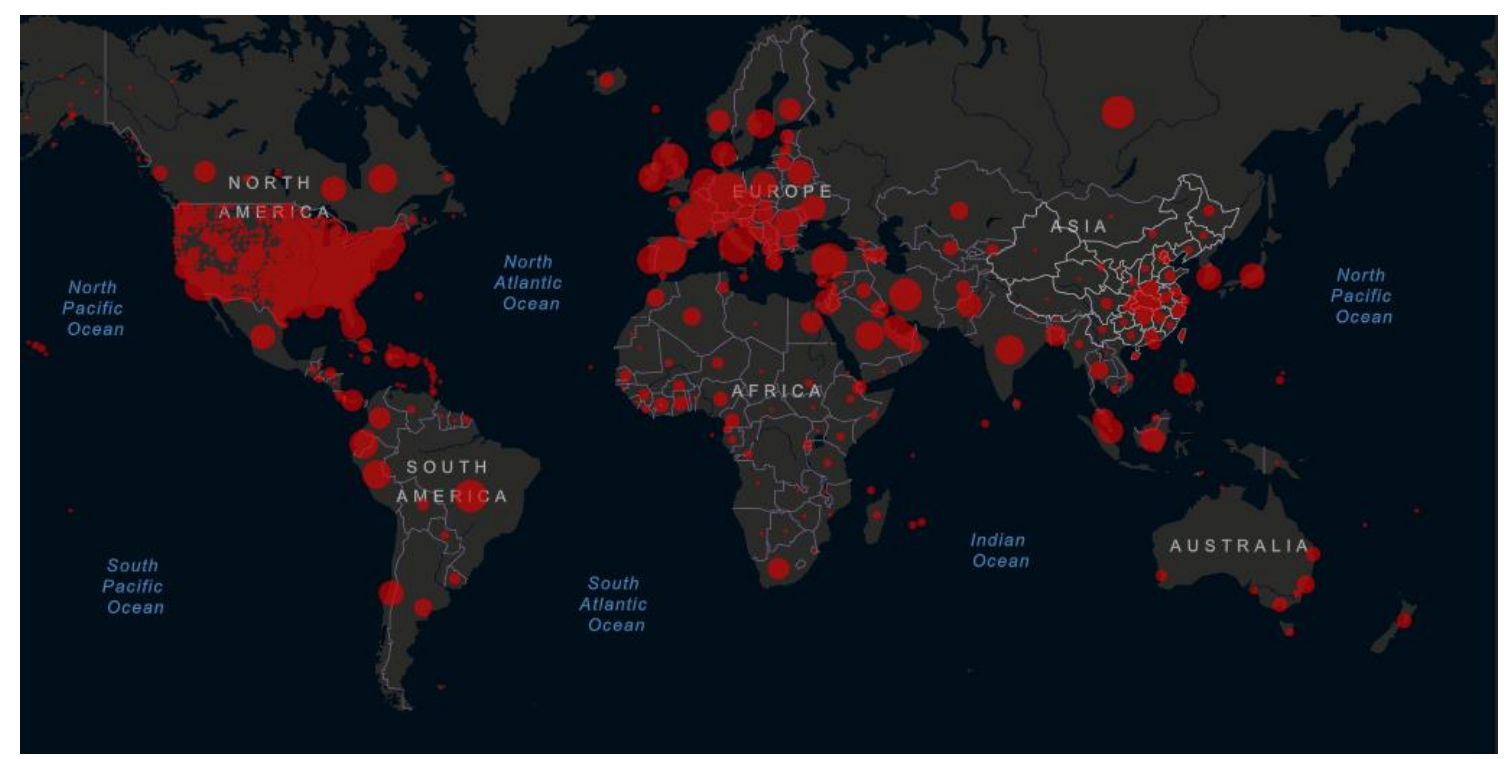

Total confirmed: $\mathbf{2 , 8 9 7 , 8 8 3}$ Total deaths: $\mathbf{2 0 2 , 8 8 0}$

Date: April 26, 2020

Figure 1. Mapping of cumulative confirmed cases of COVID-19

Source: Adapted from Johns Hopkins Coronavirus Resource Center (6)

\section{DISCUSSION ON THE IMPORTANCE OF PHYSIOTHERAPY}

In addition to medical management, current evidences about thromboembolism prevention programs report preventive benefits related to physiotherapy $(17,18)$. A recent and authoritative paper recommends that physiotherapists should also be actively involved in the management of COVID19 patients (19). Indeed, early rehabilitation, consisting of range of motion exercises and passive movements may be indicated to prevent immobilization sequelae (19-21). Hence, we suggest researchers to consider investigating in depth the role of physiotherapists for COVID-19 patients, from the first phases of the disease, in order to maintain or improve their joint mobility as well as muscle function. Undoubtedly, our call to action should be intended as a proposal (in line with previous researches), which has to go hand in hand with 1) medical recommendations and 2 ) appropriate equipment.

\section{FINAL CONSIDERATION}

Despite recent advances for the COVID-19 treatment, it is recommended that people comply with social and physical distancing measures, as well as other public health and social measures, given that prevention is the best way both to end this pandemic and to prevent possible collapses of health care systems. In this sense, affected countries should focus their efforts to balance the possible benefits and negative consequences of each intervention. Moreover, it is essential the implementation of strategies to encourage actions, including community engagement, gain trust, and limit social or economic harm (22).
Finally, we believe that an effective COVID-19 vaccine will should be a key tool in achieving a drastic decrease in the circulation of the virus, since it is not known whether there will be continued seasonal circulation of SARS-CoV-2 in some region of the world. Thus, until the situation returns to normal, it is necessary that everyone must be cautious and adhere to all guidelines issued by local, regional or national public health authorities. Good luck to all!

\section{REFERENCES}

1. World Health Organization. Coronavirus disease 2019 (COVID-19). Situation report - 70 [Internet]. Genebra: World Health Organization; 2020. Available at: https:/apps.who.int/iris/bitstream/handle/10665/331683/ nCoVsitrep30Mar2020-eng.pdf (Accessed: 26 April 2020).

2. Santacroce L, Charitos IA, Del Prete R. COVID-19 in Italy: an overview from the first case to date. Electron J Gen Med. 2020;17(6):em235. https://doi.org/10.29333/ejgm/7926

3. Minh Duc N, Duc Ha H, Anh Tuan T, Lien Bang MT, Hong Duc P, Minh Thong P. From first COVID-19 case to current outbreak: a vietnamese report. Electron J Gen Med. 2020;17(4):em208. https://doi.org/10.29333/ejgm/7867

4. Li LQ, Huang T, Wang YQ, et al. COVID-19 patients' clinical characteristics, discharge rate, and fatality rate of metaanalysis. J Med Virol. 2020. [Epub ahead of print]. https://doi.org/10.1002/jmv.25757 PMid:32162702

5. Deng Y, Liu W, Liu K, et al. Clinical characteristics of fatal and recovered cases of coronavirus disease 2019 (COVID19) in Wuhan, China: a retrospective study. Chin Med J (Engl). 2020. https://doi.org/10.1097/CM9.0000000000000 824 PMid:32209890

6. Johns Hopkins Coronavirus Resource Center. World Map [Internet]. Baltimore. Available at: https://coronavirus.jhu. edu/map.html (Accessed: 26 April 2020). 
7. Remuzzi A, Remuzzi G. COVID-19 and Italy: what next?. Lancet. 2020;395(10231):1225-8. https://doi.org/10.1016/ S0140-6736(20)30627-9

8. Yezli S, Khan A. COVID-19 social distancing in the Kingdom of Saudi Arabia: bold measures in the face of political, economic, social and religious challenges. Travel Med Infect Dis. 2020:101692. https://doi.org/10.1016/ j.tmaid.2020.101692 PMid:32330561 PMCid:PMC7172679

9. Abd El-Aziz TM, Stockand JD. Recent progress and challenges in drug development against COVID-19 coronavirus (SARS-CoV-2) - an update on the status. Infect Genet Evol. 2020;83:104327. https://doi.org/10.1016/ j.meegid.2020.104327 PMid:32320825 PMCid:PMC7166307

10. Borba MGS, Val FFA, Sampaio VS, et al. Effect of high vs low doses of chloroquine diphosphate as adjunctive therapy for patients hospitalized with severe acute respiratory syndrome coronavirus 2 (SARS-CoV-2) infection: a randomized clinical trial. JAMA Netw Open. 2020;3(4.23):e208857. https://doi.org/10.1001/jamanet workopen.2020.8857

11. Spiezia L, Boscolo A, Poletto F, et al. COVID-19-related severe hypercoagulability in patients admitted to intensive care unit for acute respiratory failure. Thromb Haemost. 2020.

12. Bikdeli B, Madhavan MV, Jimenez D, et al. COVID-19 and thrombotic or thromboembolic disease: implications for prevention, antithrombotic therapy, and follow-up. J Am Coll Cardiol. 2020. pii: S0735-1097(20)35008-7.

13. Zhai Z, Li C, Chen Y, et al. Prevention and treatment of venous thromboembolism associated with coronavirus disease 2019 infection: a consensus statement before guidelines.Thromb Haemost. 2020.

14. Tang N, Bai H, Chen X, Gong J, Li D, Sun Z. Anticoagulant treatment is associated with decreased mortality in severe coronavirus disease 2019 patients with coagulopathy. J Thromb Haemost. 2020. https://doi.org/10.1111/jth.14817 PMid:32220112

15. Casini A, Alberio L, Angelillo-Scherrer A, et al. Thromboprophylaxis and laboratory monitoring for inhospital patients with COVID-19 - a Swiss consensus statement by the Working Party Hemostasis. Swiss Med Wkly. 2020;150:w20247. https://doi.org/10.4414/smw. 2020.20247
16. Valerio L, de Balanzó X, Jiménez O, Pedro-Botet ML. Haemorrhagic exanthema due to dengue virus induced by acetylsalicylic acid. An Sist Sanit Navar. 2006;29(3):439-42. https://doi.org/10.4321/S1137-66272006000500012

17. Hillegass E, Puthoff M, Frese EM, Thigpen M, Sobush DC, Auten B. Role of physical therapists in the management of individuals at risk for or diagnosed with venous thromboembolism: evidence-based clinical practice guideline. Phys Ther. 2016;96(2):143-66. https://doi.org/ 10.2522/ptj.20150264 PMid:26515263

18. Okumuş G, Özçelik B, Sasani H, et al. Do appropriate thromboprophylaxis and routine physiotherapy prevent venous thromboembolism in intensive care unit?. Turk Gogus Kalp Dama. 2015;23(1):92-7. https://doi.org/ 10.5606/tgkdc.dergisi.2015.9440

19. Lazzeri M, Lanza A, Bellini R, et al. Respiratory physiotherapy in patients with COVID-19 infection in acute setting: a position paper of the Italian Association of Respiratory Physiotherapists (ARIR). Monaldi Arch Chest Dis. 2020;90(1):1285. https://doi.org/10.4081/monaldi. 2020.1285 PMid:32236089

20. Ceravolo MG, De Sire A, Andrenelli E, Negrini F, Negrini S. Systematic rapid "living" review on rehabilitation needs due to COVID-19: update to march 31st 2020. Eur J Phys Rehabil Med. 2020. https://doi.org/10.23736/S19739087.20.06329-7 PMid:32316718

21. Thomas P, Baldwin C, Bissett B, et al. Physiotherapy management for COVID-19 in the acute hospital setting: clinical practice recommendations. J Physiother. 2020. https://doi.org/10.1016/j.jphys.2020.03.011 PMid:32312646 PMCid:PMC7165238

22. World Health Organization. Coronavirus disease 2019 (COVID-19). Situation report - 72 [Internet]. Genebra: World Health Organization; 2020. Available at: https://apps. who.int/iris/bitstream/handle/10665/331685/nCoVsitrep0 1Apr2020-eng.pdf (Accessed: 26 April 2020). 